\title{
NOGLE TANKER OMKRING FLYTNING
}

Et fælles træk for alle samlinger er, at de udgør en eller anden form for - ofte akkumulerende - ophobninger af ting. Derfor er det sandsynligt, at de med mellemrum må flyttes, og lige så sandsynligt er det, at der til flytningen, om end ikke altid, er knyttet en udskillelse eller kassation af nogle af tingene. Desuden vil en flytning, om end heller ikke altid, stille krav om, at de flyttede ting, de ting der er blevet bevaret, opstilles på en ny måde. I begge tilfælde vil flytning derfor i reglen være præget af valg, og det er da netop også valgsituationerne og de mere eller mindre åbenlyse kriterier, der er i spil i forbindelse med valgene, som giver anledning til overvejelser, der siden kan samles op som erfaringer. Jeg skal her beskæftige mig med to meget forskellige flytninger, hvor valgene i den første angik nyopstillingen, og hvor udskillelsen var et nødvendigt resultat af denne, mens det $\mathrm{i}$ den anden flytning var udskillelsen og kassationen, der vejede tungest, og hvor valgene $\mathrm{i}$ forbindelse med nyopstillingen overvejende var af praktisk karakter. Til sidst vil jeg komme ind på begrebet identitet, sådan som det er dukket op i relation til de overvejelser, som flytningerne førte med sig.

\section{Museumsflytningen}

Den første flytning, der også er den største og mest omfattende, som det er faldet i min lod at deltage i, drejede sig om Etnografisk Samlings totale nedpakning og midlertidige udflytning af sine samlinger i forbindelse med Nationalmuseets ombygning og den efterfølgende nyopstilling af genstandene, der skulle stå klar til museets genåbning i 1992. Nedpakningen, der fulgte en velorganiseret procedure, indebar ingen valg, alt skulle med uanset den enkelte genstands art og tilstand, intet måtte kasseres, selv de mindste fragmenter, som end ikke kunne sættes i relation til noget som helst, blev registreret og nedlagt i flyttekasser i et optimistisk håb om, at de ved en senere lejlighed kunne tilføjes deres rette sammenhæng.

Det var først da nyopstillingen tog sin begyndelse, at nødvendigheden af at træffe valg dukkede op i al sin barskhed. Blandt de tusinder af ting, som samlingerne indeholdt, skulle der foretages valg af det, der skulle indgå i de nye permanente udstillinger, mens alle andre genstande indtil videre henvistes til en slags ikke-eksistens i magasinernes mørke. Valgene var i høj grad overladt til det museumspersonale, der var ansvarlig for de 
enkelte regioner, men naturligvis var de også underlagt nogle overordnede retningslinier, som forinden var blevet formuleret efter mange drøftelser. Nogle kriterier var der altså at holde sig til, men alligevel kunne situationen forekomme noget kaotisk.

$\mathrm{Nu}$ forholdt det sig ikke sådan, at man kunne gå rundt blandt genstandene og plukke det ud, som man efter bedste overbevisning og eftertanke fandt egnet til udstilling. Alt var jo pakket ned og utilgængeligt. Valgene måtte derfor træffes på grundlag af det billedmateriale, som ved hjælp af en helt ny teknik var blevet etableret under nedpakningen, hvor hver enkelt genstand blev fotograferet i farver. Siden var alle billederne blevet overført til en diskette, som kunne bruges i en computer. Det gjorde det muligt på skærmen at se samtlige genstande, som hørte til de enkelte regioner, og da der tilmed til hvert genstandsbillede var oplysninger om genstandenes mål og de materialer, de var fremstillet af, var man set fra en praktisk synsvinkel trods alt ikke så dårligt rustet.

I virkeligheden var vanskelighederne med at træffe valg da også mest af alt knyttet til det indholdsmæssige. Hvad skulle udstillingen dreje sig om, hvad var det vigtigt at få vist om den region, man havde ansvar for - og når man endelig mente at have fundet frem til nogle væsentlige temaer, fandtes der så genstande, der var egnede til at (re)præsentere og belyse disse efter ens opfattelse særligt betydningsfulde fænomener eller områder inden for regionen. Undertiden kunne det være nødvendigt at gå den modsatte vej og under-s $\emptyset$ ge, om der i samlingerne var nogle tyngdepunkter, hvor genstandsmaterialet var særlig omfattende og righoldigt, eller hvor det på anden vis tiltrak sig opmærksomhed, og på grundlag heraf forsøge at udmønte en tematik, som også ville være i harmoni med det, som man betragtede som karakteristisk i denne region. Begge fremgangsmåder krævede mange opmærksomme gennemsyn af billedmaterialet på skærmen, hvor det drejede sig om dels at være agtpågivende for ikke at overse det indlysende, dels at være forberedt på at opfange nye muligheder i genstandsmassen. Under alle omstændigheder sad man af og til tilbage med en fornemmelse af, at nogle beslutninger snarere var resultat af en vis sik-sakken-sig frem og tilbage end af helt overbevisende og lødige kriterier. Samtidig spøgte der også i ens hoved elementer af det tankegods, som i de senere år med stigende intensitet var dukket op i den antropologiske litteratur vedrørende genstandes identitet og repræsentative muligheder i en museumskontekst, løsrevet som de var fra den kultur, hvor de var blevet skabt og brugt. Endelig kunne frygten for at være styret af ikke erkendte etnocentriske ideer i valget af både temaer og genstande heller ikke uden videre manes i jorden. Altsammen forhold der under hele forløbet var med til at fastholde en ubehagelig, men trods alt måske ikke ganske uhensigtsmæssig usikkerhed.

Den region, jeg var ansvarlig for, var den indiske, og til den var der stillet to rum til rådighed. Til rådighed var også et stort og differentieret genstandsmateriale, hvor især to indsamlere, Eduard Løventhal (1841-1917) og Werner Jacobsen (1914-79), havde forsynet de indiske samlinger med mange genstande, der blandt andet udmærkede sig ved ikke blot at vidne om indisk højkultur, men også mange, der stammede fra de mere folkelige lag. Dette gjaldt ikke mindst de genstande, som var knyttet til hinduismen, hvor den dyrkelse, der fandt sted i de indiske landsbyer og blandt byernes jævne eller fattige befolkning, blandt andet var repræsenteret ved særlige guddomme, der kunne tilbedes i forbindelse med forskellige sygdomme og andre af dagliglivets ulykkelige hændelser. Det faldt derfor ret naturligt at vie det ene rum til hinduismen, både som den kom til udtryk i de store templer, og som den udfoldede sig på det folkelige niveau, ikke blot fordi der altså var mange egnede og for en museumssamling ualmindelige genstande inden for 
dette felt, men først og fremmest fordi den religiøse dimension er så tæt sammenvævet med indisk liv og de synlige udtryk for dens betydning så talrige.

Hvad angik den overordnede beslutning om dette rums indhold, bød valget således ikke på store vanskeligheder, men udvælgelsen af genstande og ikke mindst ordningen og præsentationen af dem i rummet var naturligvis ikke uden problemer, hvis man skulle gøre sig noget som helst håb om at få formidlet bare et beskedent indtryk af disse to sider af det religiøse univers. Jeg er da også langtfra overbevist om, at dette lykkedes, og at ret mange vil opfatte denne forskel, ikke mindst fordi opstillingen af genstandene var underlagt et udstillingsregi, hvor selv meget moderate scenografiske virkemidler ikke var tilladt.

Fødelinien - for nu at bruge et litterært analyseudtryk - til det andet rum var en lille samling meget ramponerede, men troværdigt udformede lerfigurer, som forestillede personer, der tilhørte de lavere eller laveste lag af befolkningen og udførte det mindre eller mindst respekterede arbejde. Ved udstillingen af denne lille samling, som tilsyneladende aldrig havde påkaldt sig særlig opmærksomhed og derfor aldrig var nået frem til en udstillingsmontre, og ved at supplere den med andre figurer af mennesker, der også befandt sig på samfundets bund, var et tema slået an, som drejede sig om de store hierarkiske for-skelle, der kendetegner det indiske samfund både økonomisk, socialt og kulturelt. Der var ikke tale om at tage direkte udgangspunkt i kastesystemet, fordi dette ville kræve en længere tekstlig udredning, som ikke hørte hjemme i en udstilling, men blot indirekte at lade det komme til syne, hvor det genstandsmæssigt lod sig gøre. Til at vise hierarkiets anden ende var der meget at vælge mellem i form af genstande af fin håndværksmæssig og kunstnerisk kvalitet, der blandt andet stammede fra indiske fyrstefamilier eller andre fornemme huse, som i forbindelse med ændrede politiske forhold efter Indiens selvstændighed midt i 1900-tallet havde måttet sælge ud af deres ejendele.

Dette rum var altså ikke blevet tildelt et på forhånd selvskrevet tema, sådan som det havde været tilfældet i det første med hinduismen, men havde fået sin udformning på grundlag af nogle få uanselige og dårligt bevarede figurer, som havde gjort indtryk ved den virkelighed, de syntes at spejle. At også dette rum havde fristet til en slags tosidig præsentation, som der genstandsmæssigt var mulighed for at etablere, var vel ikke i sig selv mærkværdigt, men det kan ikke uden videre afvises, at denne modstilling snarere var et resultat af udstillerens - in casu mit - ønske om at lade den fattige verden komme til orde over for den rige, at sammenholde de fattiges righoldige udtryksformer, der emmede af liv og fantasi - men ikke af en nøjeregnende finish - med de velstilledes fornemmere udformning af deres univers.

Ved gennemgangen af billedmaterialet dukkede også andre småsamlinger op, som appellerede til udstilling, for eksempel mange mindre dyrefigurer, der af indsamleren var betegnet som leget $\varnothing \mathrm{j}$. Med dem kunne der gøres opmærksom på dyrs centrale placering i den indiske forestillingsverden, både i den del af den, der angår det religiøse, men også på et dagligdags plan. Jeg havde desuden et ønske om at give den indiske kvinde en særlig plads i udstillingen, fordi det kvindelige aspekt i form af moderskikkelsen og som gudinder i det hinduistiske gudeparnas har så stærk en position. Men for mig var det magtpåliggende også at få dagligdagens kvinder med i udstillingen, og havde det ikke været for det scenografiske forbud, havde jeg gerne anbragt en lille gruppe kvinder omkring en brønd iklædt farverige sarier og bærende deres formfuldendte vandkrukker på hovedet. Måske et temmelig traditionelt interiør, men formidlingsmæssigt ikke til at kimse af, og med stor æstetisk appel. Kvinderne kom da også med i form af giner be- 
hængt med sarier - dette for Indien helt enestående beklædningsstykke, der først bliver til en dragt, når de seks-syv meter stof med stor kyndighed vikles om kvinden, og som samtidig er et udtryksfuldt vidnesbyrd om Indiens ældgamle og høje placering inden for tekstilfremstilling, farvning og mønsterudformning, i sig selv et vigtigt tema. Ginerne var bedre end ingenting, men kvindetemaets potentiale, og også sariens kunne måske ha-ve været udnyttet mere virkningsfuldt.

Da rummene endelig stod færdige, var det dog ikke uden en vis tilfredshed, jeg så mig omkring i dem - det forekom mig, at der var opnået en rimelig tematisk konsistens, og at genstandene tilsammen gav rummene en atmosfære af liv og farve og afspejlede noget af den mangfoldighed, som man forbinder med Indien. På den anden side voksede min tilfredshed heller ikke ind i himlen, for naturligvis tålte rummene ingen sammenligning med den brogede virkelighed, man ville møde under et besøg i Indien, ligesom det også var sandsynligt, at en inder ikke nødvendigvis ville finde deres indhold dækkende for forholdene i sit hjemland.

\section{Den almindelige flytning}

„Du kan ikke tage det med dig!“ Talemåden kan let være den, der hyppigst dukker op, når man skal skifte bolig fra flere til færre kvadratmeter, forudsat flytningen foregår i et overflodssamfund. Den får efterhånden næsten karakter af kommando til det, man er i færd med, selvom talemåden snarere er møntet på den ultimative flytning fra det dennesidige til det hinsidige, hvor ejendele bliver til efterladenskaber, og hvor det er op til andre at bestemme over tingenes videre eksistens. I begge tilfælde er der tale om brud på relationen mellem person og ting, men i det første er man dog endnu den, der er herre over, hvor bruddene skal ske. Situationen er ubehagelig, i hvert fald besværlig, for også den almindelige flytning indebærer valg, der tilmed ofte må træffes under et vist tidspres. Men i modsætning til museumsflytningen, hvor den ovennævnte sentens er vendt på hovedet, og hvor valgsituationen først dukker op i flytningens anden fase, nyopstillingen, forekommer valgene nu allerede i den første og er desuden endegyldige, der er ingen fortrydelsesret: det fravalgte bliver bragt uden for ens rækkevidde ved destruktion eller anden form for afhændelse. De kriterier, valgene træffes på grundlag af, er også mere flydende, mindre retningsgivende, når der ses bort fra indlysende begrundelser som pladshensyn.

Med en del ting, først og fremmest brugsting, går det dog relativt nemt, fordi de lader sig sortere ud fra kriterier som funktion, æstetik og pietet. Men står man med tre ting af samme art, for eksempel tre skåle, som hver især udmærker ved et af disse kriterier, kan valget i hvert fald tvinge til en vis selvransagelse: er man mest til det praktiske, det pæne eller det nostalgiske. Situationen er til at bære, så længe det drejer sig om tre skåle, der er ingen grund til panik. Men hvis øvelsen gentager sig mange gange - og det gør den som regel - kan man risikere at få et indblik i sin egen habitus, som måske ikke helt harmonerer med den opfattelse af sig selv, som man hidtil i god tro har næret.

Noget værre bliver det, når man kommer til de ting, som ikke har nogen praktisk funktion, det vil sige alt det uensartede gods i form af pyntegenstande, hyggeudstyr, gaver, souvenirs, som i tidens løb har hobet sig op, ting der hyppigt repræsenterer en eller anden lille hændelse i ens liv. Man tvinges ikke bare til en ofte lidt vemodig tur i erindringens vildnis, men også, når valg skal træffes, til en vis selvransagelse, til at se 
sig selv i øjnene og beslutte sig til, hvem man nu egentlig er eller i hvert fald gerne vil opfattes at være. Man kommer sejt og langsomt gennem processen, fårene bliver skilt fra bukkene, og man $\varnothing n s k e r$ sig ingen vej tilbage, dertil har processen været for tyngende.

B $\varnothing$ gerne udg ør dog en endnu sværere kategori. Pladshensynet er ubønhørligt, noget kan følge med, det meste må væk. En lang række valg, mange næsten smertelige, venter på at blive realiseret, men efter hvilke retningslinier? Funktionelle kriterier sikrer håndbøgernes fortsatte tilstedeværelse i ens nærhed, æstetiske kan være udslagsgivende for andre. Men hvad med de fiktive forfatterskaber. Yndlingsforfatterne er vel et must, for kan man overhovedet leve videre med sin identitet $i$ behold uden at have dem inden for rækkevidde. Man sender en medfølende og undskyldende tanke til denne verdens mange flygtninge, som har måttet lade alting bag sig - er det ikke udtryk for en lovlig forskruet og forkælet tankegang, at ens identitet skulle afhænge af bestemte bøgers tilstedeværelse i ens private univers. Det er det sandt at sige nok, men på den anden side noget må man vel have lov til at anse for indiskutabelt. Man svinger mellem trods og tvivl, og i den sindstilstand går valgprocessen videre. Alt for hurtigt er det tilladte antal kasser fyldt op med de bøger, der kan komme med, uden man dog føler sig helt overbevist om, at de trufne valg alle er lige velbegrundede. Reolerne er stadigvæk fulde, dog ikke helt genkendelige, spækket med tomme huller som de nu er. Men endnu har de ikke tabt deres kraft, det er stadigvæk dem, der bevarer rummenes fortrolighed, selvom deres indhold i virkeligheden allerede er forrådt, sådan fornemmes det - eller også er det sig selv, man har forrådt - og i dagene før antikvarboghandleren fjerner alt, har man et temmelig uafklaret forhold til de tilbageblevne bøger på reolerne. Først da disse står gabende tomme, forstår man det fulde omfang af, hvad man har måttet give afkald på - den gabende tomhed forplanter sig til ens eget jeg. Det åndelige landskab, man i så mange år har færdedes i, eksisterer ikke mere. Man står tilbage på valpladsen, vemodet får tag i en.

Lige så slemt er det, om ikke værre, når man kommer til skufferne med fotografier, breve og andre papirer. Ved synet af de mange bunker, hvoraf en stor del bærer præg af langvarig og uhensigtsmæssig opbevaring, lyder straks fristende toner i ens $\emptyset$ rer: „Du kan bare tage dem med dig - nok fylder de op, men det går nok alligevel.“ Fristelsen afvises resolut. Nu er man jo i gang med oprydningsprocessen - i ens iver efter at få gjort kål på det overflødige og bringe orden i det uordnede, bliver flytning næsten umærkeligt og ikke helt realistisk pludselig omdefineret til oprydning - nu skal der gøres rent bord, der skal ikke slæbes videre på usorterede masser, som vil være en hæmsko for det ubebyrdede liv, der lokker forude - endelig skal det lykkes at få sat sig selv fri.

Og så er man desuden kommet $i$ tanker om en scene, man engang overværede, hvor et par unge nevøer og niecer skulle rydde en gammel ugift, nylig afdød onkels bolig, og som til sidst sad tilbage med en sort affaldspose, hvori de havde proppet de breve, fotografier og papirer, de var stødt på undervejs. Disse klenodier, de resterende vidnesbyrd om et langt livs fornøjelige og mindre fornøjelige hændelser, blev nu genstand for en ungdommelig inspektion, der snarere appellerede til lattermilde kommentarer og små-filosofiske overvejelser end til forstående og medfølende betragtninger. Som drejede det sig om en lodtrækning, blev dokument efter dokument draget frem fra posen og af den hurtigst læsende underkastet et hastigt gennemsyn for at finde passager, der egnede sig til oplæsning. Lidt hjerteløst måske, men også en ganske sund reaktion hos dem, der endnu havde det meste af livet til gode, og som nok mente, at de selv kunne leve det mere muntert og utvungent, befriet for de bindinger og i deres øjne unødvendige konventionelle 
begrænsninger, der kom til syne i papirerne, men også et lidt skræmmende memento om ikke at kaste hvad som helst i grams til næste generation.

Der er altså ingen vej udenom, man må i gang. Men inden længe befinder man sig i en situation, hvor ens hu mest af alt står til at gøre kort og effektiv proces - ud med hele herligheden, hvorfor ligge under for gængse forestillinger om pietet, om vigtigheden af at bevare håndgribelige minder eller mindelser om forgangent liv. Alene tanken om at skulle gennemse og gennemleve mangt, som glemslen ellers havde befordret ud af ens bevidsthed, svækker ens mentale energi, der er mere parat til at lade sig bruge på frem-tiden end på fortiden. Måske vil noget dukke op, som kalder på glædelig erindring, men frygten for at andet kan vise sig, som vil genopleves pinligt eller smertefuldt - i hvert fald set i lyset af det, der siden er sket - forekommer lige så sandsynligt.

Samtidig melder tanken om pligten til at bevare noget af alt dette, som nok her og nu kan betragtes som ens ejendom, men som ret beset også har andre tilhørsforhold, medspiller som en del af det er i andres livshistorier. Man kommer i tanker om arvingers undertiden letsindige omgang med breve og lignende, som af en eftertid måtte betragtes som nationens eje, og som ingen - knap nok den oprindelige indehaver - havde bef $\varnothing$ jelser til at destruere. Ganske vist er det ikke den nationale historie, der risikerer at lide overlast ved en beslutning om at skille sig af med hele molevitten, højst ens families, men parallellen er trods alt til at få øje på og kan ikke uden videre sættes på porten. Men hvis man alligevel ikke har hals- og håndsret over alle disse besværlige bunker, er der så nogen mening $\mathrm{i}$ at kæmpe videre med dem? Til sidst opgiver man ævred og følger den første fristende indskydelse til at udsætte den ganske sag til efter flytningen i et fladt og ikke særlig overbevisende håb om, at man til den tid vil være bedre rustet til at betræde sorteringens gyldne middelvej. De gustne og modstridende overlæg har sejret. „Du må hellere tage det hele med dig“, lyder det nu efter den mislykkede og ugennemførte proces.

En dag er tiden endelig kommet til at fragte de fravalgte ting, hvoraf en del er fors $\emptyset$ gt afhændet til venner og allehånde genbrugsorganisationer, til den kommunale affaldsplads. Ens humør er stigende, ingen grund til fortrydelse, nu mangler kun den endelige overgivelse af tingene til de rette containere, som vil bringe deres indhold til endelig destruktion. Det føles som en befrielse, til syvende og sidst har man fået gjort ende på sin relation til disse ting, de tilhører ikke mere ens sfære, de har ingen kontekst ud over containernes indhold af andres destruktionsdømte fravalg. Livet kan gå videre - dog led-saget af en lille bitter smag af troløshed, men befriet for meget, som i en forstand fungerede som ballast, men i en anden føltes som byrde. Det er som at have fået styr på sin have. Planter er blevet fjernet, der er blevet luget ud, man har fået kontrol. Man gribes næsten af eufori og lover sig selv aldrig mere at lade sig løbe over ende af ting. Man orker ikke mere tingenes dominans, ikke mere at skulle forsøge at kontrollere den fysiske og mentale uorden, som de giver anledning til, fordi uorden tilsyneladende ikke kun i det kosmiske, men helt ned i hverdagen har en iboende tilbøjelighed til at brede sig på det ordnedes bekostning. Fra nu af skal livet være overskueligt.

\section{Identitet}

I det foregående er ordet identitet dukket op et par gange både i forbindelse med muse- 
umsflytningen, hvor det angik genstandene, og med den almindelige flytning, hvor det vedrørte den flyttende. Ordet identitet betyder vel i sin snævreste definition ikke meget mere, end at noget i kraft af visse specifikke egenskaber lader sig bestemme som det ene eller andet. Nu kan det naturligvis være særdeles nyttigt, at en kop kan identificeres og genkendes som en kop, men denne identitetsbestemmelse svarer næsten til en klassifikation, hvor genstanden på grundlag af et udvalgt og accepteret kriterium kan placeres i en bestemt kategori.

Mere interessant bliver det, hvis genstandens identitet vokser ud over den indlysende klassifikation, og det sker især, hvis den optræder i relation til eller i sammenhæng med andre genstande, eller hvis den befinder sig inden for en eller anden særlig sfære. Koppen er stadigvæk en kop også under disse omstændigheder, men for nu at bestemme og forstå dens identitet er det nødvendigt at gøre sig klart i hvilket samspil med andet, den befinder sig. Dette så meget mere som samspillet ikke sjældent vil tildele genstanden et symbolsk indhold, som kun lader sig afkode, hvis den iagttagende er fortrolig med den givne kulturs mange bagvedliggende forestillinger.

Det følgende lille eksempel fra det udstillingsrum, der handlede om hinduismen, kan måske belyse dette forhold. For at præsentere en af de vigtigste hinduistiske guddomme, den lille tykmavede elefantgud Ganesa, var der i en montre samlet nogle figurlige fremstillinger af ham foruden nogle genstande, som vedrørte dyrkelsen af denne populære gud, der er så nært forbundet med indernes daglige liv. I bunden af montren var anbragt en siddende Ganesafigur og foran den en lille pande, der havde stor lighed med en almindelig æbleskivepande, og som ifølge indsamlerens oplysninger havde været brugt til at bage kager i, som skulle serveres for Ganesa, der i den indiske forestillingsverden tillægges stor hang til søde sager. Hensigten med denne lille sammenstilling var naturligvis at give et indtryk af denne tilbøjelighed hos Ganesa, en oplysning der blev givet i den korte tekst, som ledsagede det lille sceneri, der imidlertid for at blive forstået altså forudsatte enten læsningen af tekstskiltet eller en forhåndsviden om denne meget menneskelige egenskab hos Ganesa. De to genstande lod sig naturligvis umiddelbart bestemme hver for sig som gudefigur og pande, men det var deres indbyrdes relation, sammenstillingen, der gav mening, hvis den blev afkodet som symbol på Ganesas kagetrang, der igen var symbol på hans menneske-lighed og uhøjtidelighed - egenskaber som i sidste instans måske også tildels kunne forklare hans popularitet som guddom.

Eksemplet tjener desuden til at sætte spørgsmålstegn ved den lidt arrogante påstand, som af og til fremsættes, at genstandene i en udstilling taler for sig selv. En sådan antagelse udtrykker tilsyneladende en respekt for den besøgende til selv at gå på opdagelse (også en yndet museumsfrase) blandt de udstillede genstande, uforstyrret af udstillerens fortolkninger, der måske for dem, hvis bes $\emptyset$ g er motiveret af ønsket om at beskæftige sig med tingenes synlige udtryk, deres æstetik, og for hvem deres kulturelle indhold er underordnet, vil kunne forekomme omklamrende. Men den kan også opfattes modsat som en mangel på respekt for de besøgende, der hverken har så meget forhåndsviden, at de kan orientere sig blandt de fremmedartede genstande, eller en så gavmild fantasi, at den på en eller anden måde kan give tingene mæle og identitet. Nogle af disse bes $\varnothing$ gende vil stille sig tilfreds med den eksotiske tur gennem samlingerne, andre vil forlade udstillingen med en vis følelse af afmagt.

Det er måske det førstnævnte publikum - de, der kom for at undersøge genstandenes æstetiske eller håndværksmæssige kvaliteter - en udstiller har i tankerne med sin påstand om tingenes talen-for-sig-selv, men det forekommer ubetænksomt at slå alle besøgende i 
hartkorn og hævde, at tingene taler så højt, at de kan fange alles opmærksomhed og opnå en eller anden forståelse hos de fleste. Og det forekommer arrogant ved at sætte sin lid til tingenes egentale at ville unddrage sig en formidlingsmæssig dialog med publikum, en dialog, der bør komme til udtryk både i udstillingsregiet og det tekstlige supplement til dette. Det er da også sjældent, at udstillinger vil være præget af en ensidig puritansk indstilling, men den enkelte udstiller kan vægte det formidlingsmæssige ansvar meget forskelligt.

En helt anden betænkelighed - men måske ikke uden en vis relation til det lige nævnte-drejer sig om den frygt, man som udstiller og formidler altid nærer for, at man - enten af uvidenhed eller i sin iver efter på en fiffig måde at belyse et særligt tema (som i det lille Ganesa-sceneri) - risikerer at overskride eller misbruge genstandenes kulturelt bestemte identitetspotentiale ved at placere dem i sammenhænge, som ville være fremmede for den pågældende kultur. Derfor ligger de overvejelser, der angår tingenes identitet, som en stadig anfægtelse ikke blot under selve udvælgelsesprocessen, men i lige så høj grad i forbindelse med opstillingen af de valgte genstande.

Under den almindelige flytning meldte spørgsmålet om identitet sig især, når det drejede sig om særlig belastende fravalg, hvor man kunne få en fornemmelse af, at man ved at skille sig af med dette eller hint gjorde vold mod sig selv, satte sin identitet på spil. Det var også identitetsfornemmelsen, der rørte på sig i forbindelse med den selvransagelse og konfrontation med sig selv, som valgsituationerne indimellem gav anledning til. Det er klart, at det i disse situationer drejede sig om den personlige identitet, der måske kan opfattes som et særligt konglomerat af egenskaber og træk, karakteristisk for et bestemt individ, om end der næppe vil være fuld overensstemmelse mellem det, som et menneske selv fornemmer som sin identitet, og det som den udefra af andre synes at være. Men det er også klart, at årsagen til de overvejelser, der opstod i valgsituationerne, drejede sig om samspillet mellem den personlige identitet og identiteten af de ting, som valgene angik. Dette samspil ligger tilsyneladende også til grund for brugen af begrebet identitet i den meget almindelige talemåde, hvor det hævdes, at de ting, man omgiver sig med, er udtryk for ens identitet - selvom identitet her sandsynligvis af og til burde erstattes eller suppleres med begrebet image. Forskellen mellem identitet og image ligger blandt andet i selve arten af den relation, der består mellem person og ting, hvor relationen for identitets vedkommende snarest er ureflekteret og resultat af personlige præferencer, mens den i forbindelse med image er mere eller mindre bevidst etableret ud fra $\emptyset$ nsket om at påvirke andres opfattelser og vurderinger af ens person.

Det kan være fristende at kalde image for manipuleret identitet, fordi der er tale om en manøvre, der går ud på at sløre eller helt at udviske forskellen mellem de ting, der vir-kelig repræsenterer identitet, og de ting, hvis tilstedeværelse er begrundet af deres mulighed for at udsende bestemte ønskede signaler. Altså ting, der er ude i et særligt ærinde, og hvor målet netop er, at de skal forveksles med de ting, hvis relation til personen er kendetegnet ved et utvetydigt tilhørsforhold.

Et grelt eksempel på en sådan manipulation er den skæbne, som undertiden overgår usælgelige, men fint indbundne bøger, når disse befries for deres trykte sider, og kun bogryggene er tilbage, parate til at påklæbes tomme hylstre og til derefter at sættes ind på reoler i hjem, hvor bøgers signalfunktion vejer tungt, mens deres indhold er ligegyldigt. Så ekstrem en form for manipulation er vel sjælden, men næppe de mere moderate fors $\emptyset \mathrm{g}$. Selv havde jeg som sagt en fornemmelse af, at visse fravalg truede identiteten, mens det måske snarere var i forbindelse med tilvalgene: det der skulle bevares, at der 
af og til var tale om at tilgodese imaget.

Det er vanskeligt at sammenholde identitetsovervejelserne i de to flyttesituationer, fordi der i den første er tale om tings identitetspotentiale, i den anden om samspillet mellem personlig identitet og tings identitet. Fælles for overvejelserne er dog, at det i begge tilfælde drejer sig om tings repræsentative og kommunikative muligheder, selvom det $\mathrm{i}$ det ene tilfælde angår et kulturelt univers, i det andet et enkelt menneske. 
